\title{
STANISEAW JEDLEWSKI'S SYSTEM OF EDUCATION AND SYSTEM OF YOUTH SOCIAL REHABILITATION ON THE GROUNDS OF CHOSEN WORKS ANALYSIS
}

Su m mary: The purpose of the text is to present to the reader the main theses and assumptions that Stanisław Jedlewski presented in his scientific works ${ }^{2}$. Selected letters, whose content is based on social rehabilitation pedagogy and focused on reflection on the process of juvenile resocialisation, form a certain substantive whole, whose consistency is based on scientific evidence. From them emerges a new vision of the processes of: care-upbringing, resocialisation and education of juveniles. The analysed texts also have historical value, as the author's reflections reveal a picture of the state prevailing in juvenile detention centres in the 1950s and 1960s. Due to its features, Stanisław Jedlewski's collection of reflections, theses and postulates can be deemed pedagogy and included in the output of Polish pedagogical thought.

Ke y w o r d s: pedagogy, Stanisław Jedlewski, selected letters

1 Dr hab. Małgorzata Michel, prof. UJ, Department of High School Pedagogy and the Polish Pedagogical Thought in Institute of Pedagogy at the Faculty of Philosophy of the Jagiellonian University, ul. Batorego 12, 31-135 Kraków; e-mail: malgorzata.michel@uj.edu.pl.

2 Stanisław Jedlewski (1906-1992). An outstanding Polish pedagogue, scientist, creator of the Warsaw school of social rehabilitation and the concept of juvenile resocialisation education. 


\section{Introduction}

The term pedagogy is referred to as 'the art of education"3. This is a group of methods and means used in education and upbringing, both the area of reflection of education as well as educational practice. Pedagogy, as Teresa Hejnicka-Bezwińska has written, is the conceptual category referring to the knowledge about social educational practice 4 . If we use the concept of pedagogy we think about some practices descriptions, whose subjects were willing to share with others their experiences connected with education, upbringing, training, and teaching ${ }^{5}$. The scientific heritage of Stanisław Jedlewski presented below, including the most important works, is actually a group of reflections, supported with survey results, from which emerges the new vision on raising processes, resocialisation and youth education of those who are placed in penitentiaries.

\section{A presentation of chosen Stanisław Jedlewski's works}

Stanisław Jedlewski's works contained two main threads, one of which is connected with educational engagement and refers to educational history, while the second one is connected with reflections based in resocialisation pedagogics. Stanisław Jedlewski was the first person in Poland to undertake conducting scientific analysis of the situation of youth placed in the isolation of penitentiaries and the effectiveness of the applied work methods. As an author, he was the first to use the concept of the second life, which went into theoretical considerations as well as practice in the context of issues connected with youth resocialisation. The works of Stanisław Jedlewski do not constitute only theoretical considerations based on the author's critical observations, but are an elaboration based on the results of quality research as presentations and analysis of trial data collected during: interviews, chats, observations, analysis of youths' diaries and letters, accidents protocols, investigation reports, penitentiary chronicles, directors' notes and even pupils' poems. Additionally, the studied texts of Stanisław Jedlewski contain postulates for pedagogical practice as, for example, the postulate for calling them diagnostic centres. On the basis of observations and research, the author in almost all his published works postulated for introducing the detailed quality changes which he had defined and proposed to apply in practice in connection with existing formal-law frameworks.

3 Wincenty Okoń, Nowy słownik pedagogiczny (Warszawa: Wydawnictwo Akademickie "Żak", 1996), 206-207.

4 Teresa Hejnicka-Bezwińska, "Pedagogika instrumentalna”. In: Pedagogika. Podręcznik akademicki, eds. Zbigniew Kwieciński, Bogusław Şliwerski (Warszawa: PWN, 2019), 478.

5 Hejnicka-Bezwińska, "Pedagogika...” 478. 
One of the first texts that was published after the commencement of Stanisław Jedlewski's Warsaw stage ${ }^{6}$ was the one in Kwartalnik Pedagogiczny (Pedagogical Quarterly) in 1959. It was entitled Spaczony ideat życiowy wychowanków zakładów zamkniętych (The Rotten Ideal of Life of Penitentiary Pupils) ${ }^{7}$. It can be treated as a preludium of the cycle of multiaspect considerations over the resocialisation of juveniles in penitentiaries. It is an important text for resocialisation pedagogics and research realised within this subdiscipline because the author deeply solidifies it in research methodology. The text is a report containing data collected in direct contact with juveniles in their place of residence, that is the penitentiary. Stanisław Jedlewski describes the fragment of reality that refers to life ideals, based on the conversations with the juveniles and analysed diary notes and letters. In the text the author presents the picture of the second life and its secrets, patterns of behaviour, symbolism of gestures, and the standards and rules exposed and followed by the researched juveniles. Data acquired from the research became the base for formulating conclusions and recommendations for practice. According to the author, the pupil remains under pressure of conditions and actions, which are the element of a stay in the penitentiary and are often in conflict with his individual aspirations and interests and make life difficult for him. This situation brings frustration, fear and anxiety, which directly generates exposed outside aggression and hatred. These than lead to external conflicts in a social context, while internally they raise a number of psychological and moral dilemmas.

Important - almost revolutionary in the context of previous juvenile criminals treatment - was the claim verbalised by Stanisław Jedlewski that not every juvenile is deeply perverted. Most of them are youths coming from educationally and socially neglected environments, who were lead to the situation of breaking the law's standards, which became a pass to the penitentiary by a series of adverse conditions - we would now call them risk factors. In the conditions of institutionary isolation and a total institutional environment, the juvenile is forced to fight for his social position and plans of realisation. Interpersonal context and shaping of relationships in the group through the prism of a struggle for position applies not only to relationships with other juveniles but also with educators. Moreover, the whole youth's energy is concentrated on one goal, that is leaving the penitentiary as quickly as possible. The author, summing up the considerations, concludes that in places such as correctional facilities, similar patterns as in other total institutions are formulated as a result of three factors: the institutional

6 The Warsaw stage of Stanisław Jedlewski's activities began in 1950, when he was transferred from Krzeszowice to the capital in order to organise the State Pedagogical University. A few years later, in the 1970s, he became the head of the Institute of Social Prevention and Resocialisation at Warsaw University.

Stanisław Jedlewski, “Spaczony ideał życiowy wychowanków zakładów zamkniętych”, Kwartalnik Pedagogiczny 2 (1959). 
pedagogical attitude of the management of the institution, the mechanism of aggressive and conspired criminal forces operating in juvenile groups, and the internal attitude of the individual.

In 1962, the book entitled Nieletni $w$ zakładach poprawczych (Juveniles in the Penitentiaries $)^{8}$ was published. It is a reliable study describing the situation of minors in penitentiaries, both male and female. Stanisław Jedlewski uses data obtained using methods such as interview and document examination. He obtained data from both adults (educators, directors) and youth-juveniles: from the diaries of foster children and educators, educational diaries, letters and memories of foster children, company records, incident reports, fights and other accompanying accidents, reports of investigations and rebellions, reports and comments of the penitentiaries' directors, statements of tutors, poems of pupils and the contents of songs as well as reports on student internships, personal conversations with tutors and pupils and data obtained from questionnaires. On the basis of such extensive research material, the author created the foundations of the theory of pedagogical rehabilitation of minors: 'the goal I set for myself at this stage of work, getting closer and getting to know, even in outline, the life of young people in the conditions of penitentiaries and drawing the first pedagogical conclusions about the first matters of this life's .

The aforementioned work described here is probably the first in Poland and certainly a key dissertation in Polish literature about minors imprisoned in isolation facilities, e.g. correctional facilities. In the introduction, the author calls it an attempt to search for the right way to deal with socially maladjusted youth in closed institutions ${ }^{10}$. It captures the situation of the minor and their life in the light of a holistic way possible in the light of isolation and detention in the institution. Therefore, in the book one can find a description of the psychological features of the charge and their fate in retrospective terms. Chapter I is entitled: Educational Tasks of the Institution and the Psychosocial Situation of the Minor. Chapter II is entitled identically to the article analysed above, i.e. The Distorted Life Ideal of Juveniles from Closed Institutions. In the above two chapters, the author presents a picture of young people in detention since the loss of freedom and a change in the nature of their lifestyle. In the context of the institutional situation, it shows the everyday life of minors, the rhythm of the penitentiary life, patterns of behaviour and specific behaviours related to factors of the institute.

As he writes, these formulas are the result of three factors: the institutional attitude of the management of the penitentiary, the mechanism of aggressive and conspired criminal forces exposed by the group, and the internal attitude of the individual reflected, among others, in their behaviour towards the group. The

\footnotetext{
${ }^{8}$ Idem, Nieletni w zakładach poprawczych (Warszawa: Wydawnictwo Pedagogiczne, 1962).

9 Idem, "Spaczony ideał..., 13.

${ }^{10}$ Ibidem, 14.
} 
author clearly indicates that in many penitentiaries the second factor, i.e. group strength, plays a decisive role. It is not - as the educators would like - a positive educational and socialisation impact of the peer group, but a demoralised gang or criminal gang, called by the author a terrorist organisation led by the leader. This group has the greatest impact on shaping the everyday reality of penitentiary reality in isolation and creates the foundations of a second life. In this chapter, the author describes its elements, shaping the image of terrorising the weaker, moral and physical abuse, cruel judgments, assaults, theft and sexual violence. Stanisław Jedlewski is of the opinion that improper educational work is a direct cause of the emergence and duration of a second life in correctional facilities and that it should be reformed so as to get out of the atmosphere of anguish and encroachment that accompanies minors in correctional facilities, towards an atmosphere of support and upbringing. At the same time, he notes the tragedy of the juvenile who wants to break with evil, but is not able to become disentangled from these factors.

For this reason Chapter III entitled The Way to the Shelter through the Court to the Penitentiary Should Lead to Resocialisation, contains statements about the work of shelters and the juvenile court. As can be concluded from the title, the resocialisation process should have its beginning even before bringing the minor to the institution, i.e. in the courtroom. Thus, Jedlewski postulates the educational role of the juvenile court and proposes changes in accordance with the following assumptions: a. alongside the investigation, which is necessary due to legal regulations, it is also necessary to conduct a pedagogical and moral examination, conducted by the educator, pedagogue and psychologist in a juvenile shelter; b. a juvenile court should become a preventive and educational institution; $c$. it is necessary to transform a juvenile shelter from a prison institution into a pedagogical, selection and research institution.

Chapter IV of the discussed study is entitled General Assumptions of Resocialisation and constitutes the theoretical foundation for detailed, specific and practical recommendations. They are located around the thought of the organisation of didactic and educational work and continued in the remaining chapters of the book. In them the author also shows the impact of frustrated states on the process of derailing minors, presenting a frustrated interpretation of the juvenile attitudes ${ }^{11}$. He also emphasises that those conditions which lead a juvenile to commit a crime often have their source in difficult living and random conditions, and the effect of an unfavorable company atmosphere can be intensified. The essence of the rehabilitation process in a juvenile detention centre should be to create an atmosphere aimed at stimulating the juvenile to cooperate in managing his fate. It is about involving a minor in self-determination processes, developing internal motivation and cooperation in achieving these goals not with a destructive peer

11 Ibidem, 78. 
group but with responsible adults. On a practical level, this means an educator who is understanding, kind and full of faith in the possibility of improving the pupil; providing the pupil with moral support and giving him the opportunity to speak; awakening mental needs in the ward; introducing the pupil to normal social life conditions and showing him positive prospects for the future. The burden of responsibility for upbringing is on the side of the educator, and the educational work is to be guided by the principle of raising awareness over training. Stanisław Jedlewski postulated that in order to implement this process one should use the methods of therapeutic pedagogy, thus he puts forward the thesis: educational work (with minors - author's footnote) 'should have a therapeutic character ${ }^{12}$. In this chapter, the author additionally distinguishes between the process of resocialisation and the educational process, and presents reflections related to the possibility of transforming the personality of the pupil, reaching the culmination of considerations in which he makes 'the subject consciously acting' out of the juvenile ${ }^{13}$.

The next, V Chapter of the cited work is entitled Organisation of Didactic Work in Juvenile Institutions and contains a number of postulates regarding the value of education and general and vocational education in working with minors in penitentiary isolation. There are thoroughly developed guidelines for the organisation of didactic work, indications regarding the curriculum, arrangement of didactic material, organisation of the school and the methodology of subject teaching. The author's general thesis is that school in a penitentiary cannot be a mechanical copy of a public school operating in the outside world. The penitentiary school has its own specificity, and all its problems are so characteristic that they must be included separately and adapted to the needs of a particular rehabilitation institution. The chapter is finished with methodical desiderats ${ }^{14}$.

VI, the most extensive chapter of the book, is titled Educational Methods and is of key importance to the problems of penitentiaries and their reform, constituting the essence of Stanisław Jedlewski's deliberations. The author focuses on analysing the issues of moral education and considerations around the concepts of good and evil. He is definitely against maintaining artificial segregation between individual groups in the institution. He emphasises the need for rich inter-group contacts and draws attention to the creation of not only educational groups but also groups based on cultural, sporting and economic activities. He opts for education through art and proper organisation of free time in the institute. He also draws attention to the role of film and sport in the process of education and resocialisation. What is more, and what seems revolutionary for the author's times, he

\footnotetext{
12 Ibidem,78-106.

Ibidem.

14 Ibidem, 106-157.
} 
emphasises the role of the social factor of education ${ }^{15}$. He postulates the necessity of establishing social relations of the juveniles with the wider society, i.e. opening an isolating institution to the local environment. These contacts should take place at cultural levels, and have the character of socially useful work and trips. Using the comparative procedure, he refers to semi-freedom forms and refers to examples of other countries, indicating the effectiveness of this type of impact. In addition, he proposes the introduction of a four-stage isolation period - from complete to semi-free - which would look that the pupil would spend the last six months of his stay in the juvenile institution as in a boarding school. This last period would be a test of the effects of juvenile resocialisation. Of course, the proposed solution was not new because Stanisław Jedlewski based his proposal on western solutions of the progressive system. Nevertheless, in the regime correctional system and, in addition, the political context of the 1960s, it was an act of courage. What deserves special attention in the presented book is a definite redirection of responsibility for the process of improvement and socialisation. Its vector is directed at educators; it is their moral and social attitude that causes the pupil's decision to change. Therefore, you need people who are characteristically distinctive, with pedagogical talent and self-sacrifice. Stanisław Jedlewski develops the problem of the character of educators and selection for educational and resocialisation work in the next chapter, but also in a separate article.

In chapter VII About the Educator, the author sketches the background of the educator, who in the correctional institution is a representative of the society to which the juvenile is going to return. Hence the emphasis on experience and the so-called developing of a life educator, education and a humanistic attitude towards humans. The author lists the features of a good and bad educator, the categorisation of which is based on the opinions of the juveniles. Among them are noteworthy features of a good educator, including protectiveness and caring, faith in man, an ability to talk about life topics, an ability to listen, composure, a love of trips and sport and trustworthiness. Among the features of the bad educator, those surveyed by Stanisław Jedlewski mentioned, among others, a lack of experience, lack of contact with pupils, malice and flippancy ${ }^{16}$.

The last chapter of the book, Chapter VIII, entitled For a Change in the Nature of the Penitentiaries is a set of postulates in which the author primarily asks for a change in the time of terminating isolation from life and the punitive and repressive nature of the institution. He proposes transforming juvenile facilities from that of an isolated and disciplinary nature to the form of boarding school education. The book finishes with a list of research materials that are an undoubted advantage of the analysed book. Numerous research data collected by the author are not only an illustration of the presented considerations, but are

\footnotetext{
5 Ibidem, 157-262.

16 Ibidem, 271-272.
} 
also proof of the undertaking of methodological activities related to the collection, presentation and development of the research materials along with an attempt to interpret them in such a difficult methodological area, i.e. the study of juveniles in a closed institution.

Three years later, in 1965, the text of Stanisław Jedlewski appeared in the Pedagogical Quarterly. It was entitled: The Issue of Punishment and Discipline in the Process of Juvenile Rehabilitation ${ }^{17}$. The author addresses the issues that are one of the conditions of the juvenile rehabilitation process, namely the issue of punishment and discipline. He analyses the educational system in juvenile detention centres, which is characterised by a disciplinary and isolating character, showing its elements through the prism of considerations on the role of factors disintegrating and integrating the personality of the juvenile in the process of upbringing and resocialisation. In addition to many factors complicating the integration of the pupil's personality, the author emphasises one, this as the distorted concept of the function of punishment. He believes that the incorrect concept of the function of punishment and the process of punishment is crucial for inhibiting the process of resocialisation. According to the author, punishment - which is a symptomatic attribute of the disciplinary and isolation system - is deprived of pedagogical values. On the basis of research data, he notes that punishment has become one of the indispensable elements of almost every activity undertaken by the juvenile in the institution and is an indispensable condition of life in the formal and informal context of the institution. The basic attitude of the institution staff in relation to the juvenile is punishment, both from the staff and the group commander. What is more, the informal leader and the group as a whole were punishing. Thus, the pupil learns to live in a world conditioned by the punishment.

Punishment cannot be treated as a basic educational measure; nobody can be brought up and maintained in discipline by fear. The use of punishments arouses the desire for revenge and rebellion resulting from living in constant uncertainty, fear and danger. Therefore, the educational measure should be persuasion, suggestion, setting a good example, the stimulation of ambition - generally a conversation and experience of being in a healthy, normal relationship. The considerations contained in the cited article are not free from behavioural implications of punishment, i.e. reflection on its frequency and type but also about the authority that executes the punishment, as well as the manner in which it was adopted by the charge. The conclusion of the discussion is that punishment more often inhibits the process of social rehabilitation than initiates it and provokes progression. In a situation of constant punishment, the educational process is simply impossible, among other things because the value of punishment is lowered.

17 Idem, “Zagadnienie kary i dyscypliny w procesie resocjalizacji nieletnich", Kwartalnik Pedagogiczny 2 (1965). 
Punishment deprived of an act of intellectual-moral and emotional-volitional nature is without worth. The act of punishment makes sense in a situation where punishment is a pedagogical means and can actually fulfil its educational role. This happens when the punishing person is recognised as an authority and when other educational means are used in addition to the punishment, while the educator gives an example of correct behaviour. In other words, he/she becomes a model for the pupil.

In the same year (1965), another text by Stanisław Jedlewski appeared in the Pedagogical Quarterly, entitled Rebellion as a Manifestation of the Destructive Integration of Juveniles in Institutions Run by the Isolation and Disciplinary System ${ }^{18}$. In the presented text, the author goes further in his considerations and focuses on the analysis of the phenomenon of rebellion in a situation of isolation and imprisonment. At the same time, he treats the rebellion as a situation of extreme aggression of peak intensity, involving a group of juveniles aiming to achieve their goals through direct assault on their opponents, in this case the educators. Rebellion at the correctional facility is often accompanied by theft, robbery and arson. The situation of rebellion on the territory of the correctional institution is an educational defeat, which is a defeat of the efforts of educators, pedagogical methods and means, ideas, educational actions and the whole system. The essence of this failure and defeat of the educators is the overthrow of the educational authority and then the social disintegration of the juveniles as a collective. Rebellion also has an impact on the individual units. The defeat is also the destruction of the common good, injury to other people and the uncritical euphoria of the juveniles. The only success of rebellion on the premises of the penitentiary, paradoxical in essence, is the integration of the pupils. Stanisław Jedlewski calls it destructive integration, as it is anti-systemic and is directed at educators. This is a second life victory, the author acknowledges.

In the journal Teacher and Upbringing in the same year (1965), an article by Stanisław Jedlewski appeared whose essence was reflection on the character of the educator. The text, entitled Autocratic Educator in the Resocialisation of the Juveniles ${ }^{19}$ contains the critic on the isolation-disciplinary system. Against this background, the author sketches the background of a contemporary for him educator, showing his autocratic character. The assumption is, however, that it is the isolation and disciplinary system that generates authoritarian attitudes in educators. The introduction of the oppressive system meant that educators with high qualifications, educated and with broad cultural and social horizons with humanities, were not sought. It was enough for the educator to be strong and able to monitor

18 Idem, "Bunt jako przejaw integracji destruktywnej nieletnich w zakładach prowadzonych systemem dyscyplinarno-izolacyjnym”, Kwartalnik Pedagogiczny 4 (1965).

19 Idem, "Wychowawca autokratyczny w resocjalizacji nieletnich", Nauczyciel $i$ Wychowanie 5-6 (1965). 
effectively. The group management criticised by the author is based on despotism, power and the fear caused among the pupils. The educator is in fact not an educator because he has no competences constituting him in this role; instead, he uses violence, i.e. screaming, threats, often acts of physical violence. The criticism of these educators at that time in juvenile penitentiaries made by Stanisław Jedlewski was in line with the general criticism of the system and was consistent with previous texts criticising the system itself or the educational means used in it, mainly based on punishments. In the summary of the analysed text, Stanisław Jedlewski puts forward the thesis that in the case of socially maladjusted youth it is a mistake to assume that educational effects will be achieved by inducing fear, prohibition and terror and by using only administrative or regulatory methods of work. In addition to the lack of effectiveness of these activities, pupils will quickly become convinced of the bad will of the educator.

In 1996, Stanisław Jedlewski published another book: Pedagogical Analysis of the Disciplinary and Isolation System in the Rehabilitation of the Juveniles ${ }^{20}$. As he emphasises, 'this work is the evaluation of the problems raised in my previous book $^{21}$. The author - although making a critical analysis of the disciplinary and isolation system in his work with juveniles - in the introduction clearly indicates the fact that the book is not only an expression of criticism and a negative image of correctional facilities. He strongly emphasises the appreciation of educators, dedicating to them the above work: 'those people, regardless of hardships, and even personal danger, give their good will and health to the case, which by its always proper setting brings disproportionately small results. In the book I often express full recognition for those educators, teachers and directors who were able to find the right methods of social rehabilitation, thanks to which their efforts are crowned with valuable achievements ${ }^{22}$. The purpose of the book is to analyse individual elements of the isolation and disciplinary system, to show its non-compliance with the assumptions of special education and rehabilitation tasks. As in the case of the previous book, here the reflection is based on data collected from the field, which the author obtained with the help of his master students, and they come from conversations with the juveniles and educators of correctional institutions.

In the first part of the book, the author criticises the isolation and disciplinary system, presenting the situation of children in isolation and discipline, while proving that such a system is not conducive to the implementation of educational tasks. In the following chapters, he concentrates his considerations on the presentation of tasks and the social function of institutions that rehabilitate socially

20 Idem, Analiza pedagogiczna systemu dyscyplinarno-izolacyjnego $w$ resocjalizacji nieletnich (Warszawa: Ossolineum, 1996).

21 Ibidem, 9.

22 Ibidem. 
maladjusted youth (Chapter I). Based on the data obtained from the research area in Chapter II, it indicates certain factors constituting the essence of the criticised system, including lack of selection, isolation, crowding, and inappropriate staff ${ }^{23}$. In Chapter III, the author reflects on the negative function of punishment and discipline as attributes of the isolation and disciplinary system, and also addresses an important problem that is part of the second life, namely the use of non-statutory penalties ${ }^{24}$. Next, he analyses upbringing damages resulting from the use of non-professional educators to punish in accordance with the principle of 'pereat mundus fiat iustitia ${ }^{25}$. Chapter IV deals with issues related to the educator's features, and then proceeds in Chapter $\mathrm{V}$ to research-based considerations regarding the determinants of attitudes of juveniles towards themselves and adults in the workplace context. This part finishes with exemplifications of the inefficiency of the isolation and disciplinary system in the form of rebellions and escapes from juvenile detention centres (chapters VI and VII) and the conclusions contained in chapter VIII.

In the second part of the book, Stanisław Jedlewski focuses on showing the methods and means of social rehabilitation that allow overcoming negative and unfavourable elements of the criticised system in educational work, thus ensuring the achievement of positive results in the process of education. In chapters IX and $\mathrm{X}$, the author focuses his considerations on the analysis of individual psychological and characterological features of the juveniles. Then in chapter XI he goes on to considerations related to pedagogical and therapeutic integration activity as a condition for the effectiveness of social rehabilitation. The thesis of the discussion is that upbringing a socially maladjusted person, if he or she is about to return to society, cannot be isolated. Therefore, from the first moments of the pupil's stay in the penitentiary, it is necessary to strive to establish correct contacts of the juvenile with the social environment and overcome isolation.

Stanisław Jedlewski opposes the criticised system by creating in Chapter XII 'an outline of the reform of the organisation of activities that rehabilitate socially maladjusted youth' ${ }^{26}$ - a system whose assumption is 'the consistent introduction of young people to a normal life in society by means of gradual adaptation to freedom in situations requiring more and more responsible self-management, while still remaining under the educational care of the penitentiary ${ }^{27}$. The main role in the postulated system should be played by so-called libertarian methods of upbringing. The author also proposed a five-step educational workflow, as an ideal organisational system for fulfilling his postulates. Because, as he clearly indicated, as not every juvenile could be included in the proposed system, the first

\footnotetext{
23 Ibidem, 20.

24 Ibidem, 27.

25 Latin: "Even if the world were to die, let the justice be done".

26 Jedlewski, Analiza pedagogiczna..., 152.

27 Ibidem, 156.
} 
stage of diagnostic and selection character was crucial. Certainly, people such as sociopaths, characteropaths, people with mental disorders and intellectual disabilities require isolation. There was also a demand to change the system of training the educators so that they were equipped with work skills at each of the proposed stages. In Chapter XIII of the presented book, the author discusses selected systems of re-education of juveniles outside Poland, placing his proposal on 'pedagogical humanism in penitentiary thought of the mid-nineteenth century' $^{28}$. Pedagogical inspirations include solutions by Walter Crofton, William Georges, Swiss post-cure and French semi-liberté institutes. The closing considerations concern the idea of probation. The book is additionally crowned with annexes containing the characteristics of selected institutes and systems attempting to apply semi-liberal resocialisation measures against a comparative background.

The fundamental work, which is the culmination of previous research and theoretical work in the field of resocialisation pedagogy is a two-author book entitled Resocialisation Pedagogy ${ }^{29}$, developed by Stanisław Jedlewski in cooperation with Czesław Czapów. The first academic textbook on social prevention and rehabilitation of juveniles is a compendium of knowledge on the education of socially maladjusted youth. As can be read in the preface, the authors address 'not only students of pedagogy, students of psychology and sociology interested in social pathology, and educators involved in the education of socially derailed people $[\ldots]$ and anyone who wants to shape and develop the personality comprehensively and effectively of a pupil and protect him from the danger of antagonistic and destructive conflict with the society ${ }^{30}$.

The thoughts included in the textbook are interdisciplinary, containing studies in areas such as law, pedagogy, psychology, sociology, criminology, praxeology and philosophy. The content of these disciplines is synthetically included in the context of socially maladjusted people and the purpose of such an approach is 'to restore more or less socially derailed people to the society as well as (shown in the author's footnote) such actions that effectively prevent derailment of youth ${ }^{31}$. What's more, the textbook content was consulted with practitioners - employees of many resocialisation institutions whose activities are dedicated to juveniles. The presented textbook is also valuable because it is an example of a skillful combination of theory and practice and an attempt to apply theoretical thinking to everyday social rehabilitation work. Many reflections and theses are based on thoroughly conducted scientific research. Although today many of the reflections presented have lost their relevance, at least because of the ideologisation of those content, it is worth exploring this work cognitively. The book consists

\footnotetext{
28 Ibidem, 173-191.

29 Stanisław Jedlewski, Czesław Czapów, Pedagogika resocjalizacyjna (Warszawa: PWN, 1970).

30 Ibidem, 6.

31 Ibidem, 5 .
} 
of six chapters, of which the first three are theoretical and are: I. The Science of Social Rehabilitation Education, which presents the taxonomy of sciences and the connections of social rehabilitation pedagogy with other sciences; II. Problems, Methods and Theorems of Social Rehabilitation Pedagogy, where the authors focus on the goals of social rehabilitation education in the context of education theory; III. Resocialisation as a Process of Activating Re-education, which is a chapter that places the issues of rehabilitation pedagogy in Poland and defines its basic problems.

The remaining chapters are of a methodical nature and deal with techniques and methods used in resocialisation institutions profiled to work with the juveniles. These are: IV. Praxeological Model of Social Rehabilitation Education, defining the principles of social rehabilitation and its stages, taking into account not only the process of social rehabilitation in the strict sense but also paying attention to the issues of social prevention; V. Techniques and Methods of Resocialisation Education, where methods and techniques of resocialisation education are characterised, among others anthropotechnics and culture techniques; VI. Institutions and Systems of Social Rehabilitation Education is a chapter characterising individual institutions of social rehabilitation of juveniles in a cultural and social context, and containing a typology of social rehabilitation systems in both institute and freedom conditions. It is worth noting the fact - which the authors point out in the preface - that the textbook has filled an important gap and that Stanisław Jedlewski and Czesław Czapów faced the difficult task of creating a study that would give a full picture of rehabilitation pedagogy. The textbook is also a continuation of Polish pedagogical thought in the field of working with people who require special educational methods. The authors create a continuation of reflection based on special pedagogy, drawing from the writing tradition of, among others, Maria Grzegorzewska. However, the concept of social rehabilitation education they present is much broader and, for those times, innovative in its comprehensiveness and coherence.

In 1974, a text by Stanisław Jedlewski was published, in the journal Psychological Health entitled On the Need to Reform the Rehabilitation System of Socially Maladjusted Youth ${ }^{32}$. The author does not so critically refer to the contemporary juvenile resocialisation system but postulates the urgent need to introduce fundamental changes through not only minor, local actions but also through global reform throughout the country. According to the author, the second-life terror prevailing in the penitentiaries prevents any actions aimed at achieving positive educational effects. The reform should entail modernisation of the institutes, breaking with the isolation and disciplinary system, and breaking the teaching process with the class-lesson system. The educational and didactic process should

32 Stanisław Jedlewski, "O potrzebie reformy systemu resocjalizacji młodzieży niedostosowanej społecznie”, Zdrowie Psychiczne 34 (1974). 
be based on the individual diagnosis of each pupil, and on the implementation of individual goals through the selection of methods and educational and didactic means adapted to the personality status of a particular pupil.

Referring to didactic processes in resocialisation in 1976, a work edited by Adam Podgórecki included a text by Stanisław Jedlewski entitled Didactic in the Process of Resocialisation ${ }^{33}$. The considerations contained therein are focused on the school, mainly due to the negligence of education in juveniles who go to the penitentiaries. The author thinks that in the opinion of juveniles the school has pejorative overtones, associated with school failures, low academic performance and humiliation. We should look for the answer to the question about how to achieve teaching and educational goals in their case, without losing the educational and resocialisation goals. In other words, how to prepare a juvenile with his specificity for future life? Stanisław Jedlewski postulates the reform of the teaching system consisting in breaking with the class-lesson system for the creation of subject laboratories, well-equipped with literature, teaching aids and necessary devices conducive to intellectual work. In the field of curriculum reform, Jedlewski called for a change at the level of both structure and content selection. The criterion of the scope of the programme was to be its usefulness, i.e. the pragmatic use of these messages and skills that pupils should be equipped with in order to fulfil their social and professional obligations in the future. The school curriculum should be relieved of unnecessary content ballasts and topics not related to life but constituting dead knowledge. Rejection of unnecessary content should not violate the discipline's system, its logic and basic elements of knowledge.

At the same time, Jedlewski emphasised the educational values of programme content which should be of a moral and social nature, shaping the attitudes towards work, social ownership, responsibility and internal discipline, as well as the attitude towards the homeland, family and parents as well as weaker people. The author postulated the introduction of the form that we would today call tutoring, i.e. the individual work of the pupil under the guidance of a teacher. At the same time, classes were to be conducted using activating methods such as problem, team and individual methods, and those implemented only at school. In the boarding school, juveniles will not do their homework because there will be other, team-based classes teaching group and society life. The student team should not be larger than 10-12 students, and school and behaviour grades were to be scored. It was about eliminating grading, in particular negative grades, for awakening internal motivation, encouraging work and study, and effort.

33 Idem, "Dydaktyka w procesie resocjalizacji”. In: Zagadnienia patologii społecznej, ed. Adam Podgórecki (Warszawa: PWN, 1976). 
The same study included another article by Stanisław Jedlewski entitled System of Institutions Solving Problems of Social Pathology $y^{34}$. In this text, the author presents the organisational scheme of a social rehabilitation institutions. He had included to this group - which was also a peculiar novelty - not only typical educational and resocialisation institutions, such as an educational emergency service, educational centre, orphanage, shelter for juveniles or a penitentiary, but also psychiatry departments, juvenile courts, a telephone helpline, family or educational and vocational life, youth clubs and culture centres, youth guardianship centres, voluntary labour corps and the Polish scouting association. At the same time, he strongly emphasised the need for cooperation between these institutions at the local level in order to help the juveniles in terms of both social prevention and resocialisation. He also emphasised the importance of mass media such as radio and television. The article is crowned by the basic principles of social prevention and social rehabilitation of youths together with educational, didactic and organisational assumptions. He strongly emphasised cooperation with the minor's family and advocated professional care for the juvenile in the local community after leaving the correctional facility.

In 1978, Stanisław Jedlewski's last book about juvenile establishments was published, which was entitled Renewal of Juvenile Penitentiaries ${ }^{35}$. The author constitutes here the postulates introduced in his earlier literature, arguing with the collected research material in the form of data from employees of correctional facilities. The book contains eight chapters. The first of them: I. Comments on the Current State of Implementation of Tasks of Juvenile Establishments is an optimistic statement of the progress that has been made in the educational layer in juvenile penitentiaries. In this chapter he strongly emphasises the need to open correctional facilities to the local environment and cooperate with it, as well as with a juvenile's family. Chapter II An Outline of the Reform of the Organisation of Social Rehabilitation Activities, as the title indicates, is an outline of a vision of systemic change that would take place in juvenile institutions. In Chapter III, entitled The Important Role of Diagnosis in Working with Minors, the author presents a holistic approach to the diagnosis of a juvenile, which includes the study of somatic and mental health, its neurological and psychiatric condition. He advocates that the diagnosis should also include the juvenile's environment, i.e. family, caregivers, school and peers. Only making such a comprehensive diagnosis gives you the opportunity to make therapeutic and pedagogical forecasts, which are the basis for directing the minor to the appropriate institution and organizing an individualized resocialisation process.

34 Idem, "System instytucji rozwiązujących problemy patologii społecznej”. In: Zagadnienia patologii...

35 Idem, Odnowa zakładów dla nieletnich (Warszawa: WSiP, 1978). 
The subject of Chapter IV is The Coupled Role of Prevention with Resocialisation Activities in the Institution. The author emphasises the relationship between social prevention and the rehabilitation process, treating them as a whole. 'You cannot think of resocialisation without preventio' ${ }^{36}$. According to Stanisław Jedlewski, these are phenomena that intertwine and complement each other in the educational process. Although each of them meets different goals, the effectiveness of the social rehabilitation process also depends on preventive actions. Chapter V is entitled Pedagogical Humanism of the Educator in his Social Rehabilitation Activities and is a creative development of earlier texts criticising educational authoritarianism. This chapter includes a methodological aspect in which the author presents the results of the research comparing the data obtained from the juveniles in terms of answering the question about the characteristics of a good educator. Chapter VI, entitled Penitentiary as a Social Rehabilitation Institution, according to postulated didactic activities, deals with school in the correctional institution, its organisational forms, plans and curricula. The author assumes that it is the school that is to be the way to the pupil's freedom in the penitentiary, therefore the knowledge transferred must be closely connected with life and prepare the pupil for the roles to be fulfilled in the future. Due to the fact that only vocational training was possible in company schools, the author postulated close cooperation of the school with production plants in local areas in order to best prepare the pupils for starting their professional work. Great emphasis was placed on sport education and culture technology. This idea is developed in the next, Chapter VII, entitled Innovative Proposal of the Method of Social Rehabilitation Cooperation with Juveniles in Freedom Education Teams, where it presents the structural outline of the modernised system of social rehabilitation of socially maladjusted youth in the form of a project. These freedom groups were intended to be something like separate apartments ${ }^{37}$, in which the residents will be small groups of young people, together with an educator coming from outside. Such a facility, which is the last stage of the rehabilitation process (after a stay in a closed facility), should be embedded in a local environment, e.g. in a housing estate among other people. In the final Chapter VIII Prophylactic Follow-up Care, the author focuses on the situation of a juvenile who has already left the correctional facility, claiming that the natural form of working with a minor at this stage should be protective and preventive activities in the context of the idea of probation. This type of follow-up care would include preparing a family environment for the adoption of a juvenile, help in professional stabilisation in the workplace, inclusion in a constructive peer group, meeting housing and material needs (housing and shelter), ad hoc assistance in dealing with life and clerical problems, as well

36 Ibidem, 43.

37 Currently, this form of work with minors is used by so-called self-empowerment flats. 
as guardian's care. The author repeatedly emphasises the humanistic dimension of the organisation of this type of care.

In 1982, Stanisław Jedlewski wrote another text in the field of juvenile resocialisation pedagogy, namely Resocialisation in Juvenile Institutions ${ }^{38}$, published in the Nowa Szkoła (New School) journal. In this text, the author again postulates the departure from the isolation and disciplinary system in favour of the educational system as a sine qua non condition for the effectiveness of the juvenile resocialisation process. He argued that we should not and cannot 'resocialise youths in the crowd'. There should be a maximum of 10 pupils per one educator so that everyone has a chance to form the relation of educator - pupil and not one of the pupil - guardian, penalty executor, officer. In this article, the author also strongly emphasises the meaning of stigmatising juveniles in the isolation and disciplinary system, where the position of the educator as a guardian generates the position of a minor as a criminal who needs and should be guarded. After the court's ruling on placing a juvenile in a correctional institution, a new stage in his life should begin, which in turn should lead to different attitudes conducive to good social coexistence. According to the author, this also guarantees the educator's faith in the sense of their own work and the humanistic context of interactions, along with the faith of the educator in the development and capabilities of the juvenile.

\section{Summary and conclusions}

The aim of the article was to present texts selected from the achievements of Stanisław Jedlewski. The material presented above, whose content is grounded in social rehabilitation pedagogy, is a reflection based on the results of the author's research, which led to creating a coherent concept of social rehabilitation education that meets the conditions of being pedagogy. To recapitulate, the following threads and theses are clearly visible in the achievements of Stanisław Jedlewski:

1. Critical analysis of the disciplinary and isolation system of juvenile institutions, based on scientific evidence;

2. Critical analysis of the education system in institutions for juveniles, based on the class-lesson system, based on scientific evidence;

3. Introducing to Poland the methodology of qualitative research in a difficult area, which is a juvenile penitentiary;

4. Introduction into the field of rehabilitation pedagogy the concept of the second life of a correctional institution;

38 Stanisław Jedlewski, “Resocjalizacja w zakładach dla nieletnich”, Nowa Szkoła 3 (1982). 
5. Creating a concept of juvenile resocialisation education, based on a humanistic approach to the pupil, assuming progression, individualisation of the rehabilitation process from the diagnosis and design of educational and resocialisation methods, to their implementation and assessment of effectiveness;

6. A comprehensive approach to the resocialisation process, consisting of care-educational, preventive-resocialisation and educational interactions;

7. Introduction of the postulate of a comprehensive juvenile diagnosis, including biopsychosocial health, included in the context of family and local factors;

8. Introducing the idea of selecting juveniles after diagnosis and assigning them to different types of interactions depending on the level of demoralisation;

9. Postulating the opening of the juvenile resocialisation system for work with the family and the local environment, using the idea of probation;

10. Paying attention to the trajectory of the fate of juveniles and examining their past;

11. Creating a concept for a new vision of a company educator working with juveniles (from authoritarianism to humanism);

12. Creating a new category of the tutor-foster relationship and shifting the burden of responsibility for the effectiveness of the social rehabilitation process from the foster child to the educator.

\section{Pedagogia Stanisława Jedlewskiego na podstawie analizy dzieł wybranych}

Streszczenie: Celem tekstu jest zaprezentowanie czytelnikowi głównych tez i założeń, jakie $\mathrm{w}$ swoich pracach naukowych przedstawiał Stanisław Jedlewski. Wybrane pisma, których treści ulokowane są $\mathrm{w}$ pedagogice resocjalizacyjnej i skoncentrowane na refleksji dotyczącej procesu resocjalizacji nieletnich, tworzą pewną całość merytoryczną, a jej spójność oparta jest na dowodach naukowych. Z nich wyłania się nowa wizja procesów: opiekuńczowychowawczych, resocjalizacyjnych i edukacyjnych nieletnich. Analizowane teksty mają również wartość historyczną, gdyż z rozważań autora wyłania się obraz stanu panującego w zakładach poprawczych dla nieletnich w latach 50. i 60. XX wieku. Zbiór refleksji, tez i postulatów Stanisława Jedlewskiego można nazwać pedagogią i umieścić w dorobku polskiej myśli pedagogicznej.

Słow a kluczowe: pedagogia, Stanisław Jedlewski, pisma wybrane 


\section{References}

Monographies:

Hejnicka-Bezwińska, Teresa. "Pedagogika instrumentalna”. In: Pedagogika. Podręcznik akademicki, eds. Zbigniew Kwieciński, Bogusław Śliwerski. Warszawa: Wydawnictwo PWN, 2019.

Jedlewski, Stanisław. Analiza pedagogiczna systemu dyscyplinarno-izolacyjnego $w$ resocjalizacji nieletnich. Warszawa: Wydawnictwo Ossolineum, 1966.

Jedlewski, Stanisław. Nieletni w zakładach poprawczych. Warszawa: Wydawnictwo Pedagogiczne, 1962.

Jedlewski, Stanisław. Odnowa zakładów dla nieletnich. Warszawa: WSiP, 1978.

Jedlewski, Stanisław, Czapów, Czesław, Pedagogika resocjalizacyjna. Warszawa: Wydawnictwo PWN, 1970.

Articles in journals:

Jedlewski, Stanisław. "Bunt jako przejaw integracji destruktywnej nieletnich w zakładach prowadzonych systemem dyscyplinarno-izolacyjnym”. Kwartalnik Pedagogiczny 4 (1965).

Jedlewski, Stanisław. "O potrzebie reformy systemu resocjalizacji młodzieży niedostosowanej społecznie”. Zdrowie Psychiczne 34 (1974).

Jedlewski, Stanisław. "Resocjalizacja w zakładach dla nieletnich”. Nowa Szkoła 3 (1982).

Jedlewski, Stanisław. "Spaczony ideał życiowy wychowanków zakładów zamkniętych”. Kwartalnik Pedagogiczny 2 (1959).

Jedlewski, Stanisław. "Wychowawca autokratyczny w resocjalizacji nieletnich". Nauczyciel i Wychowanie 5-6 (1965).

Jedlewski, Stanisław. "Zagadnienie kary i dyscypliny w procesie resocjalizacji nieletnich”. Kwartalnik Pedagogiczny 2 (1965).

Chapters in works under edition:

Jedlewski, Stanisław. "Dydaktyka w procesie resocjalizacji”. In: Zagadnienia patologii społecznej, ed. Adam Podgórecki. Warszawa: Wydawnictwo PWN, 1976.

Jedlewski, Stanisław. "System instytucji rozwiązujących problemy patologii społecznej”. In: Zagadnienia patologii społecznej, ed. Adam Podgórecki. Warszawa: Wydawnictwo PWN, 1976.

Other:

Okoń, Wincenty. Nowy słownik pedagogiczny. Warszawa: Wydawnictwo Akademickie “Żak”, 1996. 